\title{
Religion, Expression, and Patriotism in Russia: Essays on Post-Soviet Society and the State
}

\author{
Sanna Turoma, Kaarina Aitamurto och Slobodanka Vladiv-Glover (red.) \\ Stuttgart: Ibidem 2019 \\ 220 sidor. ISBN 9783838213460
}

Recenserad av Yuliya Yurchuk [postdoktor, Institutionen för historia och samtidsstudier, Södertörns högskola, yuliya.yurchuk@sh.se]

Många forskare skriver om en "conservative turn» - ett konservativt skifte - som den viktigaste förändringen i Rysslands inrikes- och utrikespolitik sedan 2000. Detta skifte karakteriseras av en negativ inställning mot utländskt inflytande och en strategi inriktad på att bevara den egna identiteten som betraktas som en motsats till andra länder, särskilt i västvärlden. En av de främsta aktörerna i detta konservativa skifte är den ryska ortodoxa kyrkan, som inte bara försöker öka den ortodoxa kyrkans ställning som en viktig del av den "ryska» identiteten i Ryssland utan också sprider sina konservativa värderingar under benämningen "ryska värderingar» utanför Ryssland, särskilt i de länder där den ortodoxa tron är starkast. I detta sammanhang är den kristna ortodoxa tron en viktig del som skiljer de ryska värderingar man propagerar för från övriga värderingar. Konservativa värderingar som sprids av den ryska ortodoxa kyrkan påverkar för övrigt lagstiftningen vad beträffar handlingar som kan kränka "troendes känslor». Till följd av det formas dagens ryska kulturpolitik i stor utsträckning av inflytandet från de konservativa värderingar som stöds av både kyrkan och staten.

I boken Religion, Expression, and Patriotism in Russia: Essays on Post-Soviet Society and the State närmar sig författarna analysen av olika kulturpolitiska inriktningar i Ryssland sedan 2010. Som Sanna Turoma och Kaarina Aitamurto påpekar i inledningen är den nutida kulturpolitiken i Ryssland huvudsakligen en konservativ identitetspolitik. Genom att analysera nyligen utgivna statliga dokument om kulturpolitik visar författarna att kultur används som en viktig resurs för att sprida konservativa värderingar och för att begränsa liberala och kritiska röster. I den statliga identitetspolitiken betraktas kultur som en resurs med samma betydelse som övriga naturresurser. Detta "naturaliserade» begrepp beskriver kultur som en drivkraft i statens framställning av en särskild rysk "civilisation» där Ryssland och det ryska folket 
återges som bärare av en speciell mentalitet och äkthet (mentalitet rossijjkogo naroda och tsivilizatsionnaja samobytnost'). Den av Kreml propagerade patriotismen lägger grunden till Rysslands kulturproduktion och utbildningssystem, påpekar författarna (s. 12). Kultur och utbildning ska motsvara "traditionella ryska värderingar» enligt den konservativa identitetspolitiken. Här ger staten Moskvapatriarkatet en speciell ställning eftersom den ortodoxa kyrkan anses vara en viktig del av den ryska identiteten. I ortodoxa sammanhang har kyrkan ofta lierat sig med staten. Det speglas även i konceptet "symfoni» som beskriver vilken harmonisk karaktär som relationerna mellan kyrkan och staten uppvisar. I den bemärkelsen kan man se på dagens samarbete mellan stat och kyrka i Ryssland som ett led i de långa och invecklade relationer där både staten och kyrkan har sina egna motiv och sin egen logik för att förstärka eller försvaga samspelet. I dagens läge är en konservativ identitetspolitik något som gynnar både staten och kyrkan. Till följd av detta är samarbetet synnerligen intensivt.

Kapitlen i boken beskriver mycket bra hur komplexa relationerna är mellan staten och kyrkan. Varje kapitel belyser särskilda aspekter i kulturpolitiken där kyrkan eller ortodoxin spelar en viktig roll. Boris Knorre fokuserar på "politisk ortodoxi» som används som ideologiskt begrepp och dess inflytelse på militarisering och krigsberättigande utifrån religionens perspektiv. Författaren visar hur ortodoxa nationalistiska teoretiker inom kyrkans ledning försöker presentera ortodoxin som en politisk religion som försvarar kriget genom att skapa preciserade kategorier av fiender, vänner, troende och icke-troende. Dessa teoretiker ansluter sig till Huntingtons idéer om "den ortodoxa civilisationen» som används av Moskvapatriarkatets ledarskap i konstruktionen av "den ortodoxa världen». Patriarken Kirill (Gundjaev) hade varit en av de viktigaste förespråkarna av detta begrepp långt innan han blev den rysk-ortodoxa kyrkans patriark 2009. "Den ortodoxa världen" blev en del av "den ryska världen» i diskursen som inkluderar alla länder med ortodox majoritet. I radikala former propagerar förespråkare av politisk ortodoxi för atomvapen och krig mot alla som inte stödjer Moskvapatriarkatet, då de anses som icke-troende som till sist hindrar de troendes räddning. Denna ideologi blev särskild påtaglig under protesterna i Kiev (november 2013-februari 2014) och i kriget i östra Ukraina sedan våren 2014. Politisk ortodoxi blev huvudideologi för den ryska ortodoxa armén militaristiska grupper av separatister och ryska medborgare i östra Donbass. Då ser man att ortodoxi blir en dogm som förstärker Rysslands militarisering.

I sitt kapitel analyserar Mikhail Suslov kulturella produkter som tillhör den "ortodoxa kulturen». Han visar att även om majoriteten av den ryska befolkningen identifierar sig med "ortodox kultur» är rena ortodox-kulturella produkter inte populära bland befolkningen. Till exempel fick barnfilmen The Extraordinary Travelling of Serafima, som handlar om helgonet Serafim av Sarov, bara 500.000 besökare på biografer i Ryssland, jämfört med Disneys Frost som fick 5 miljoner besökare på Rysslands biografer. På så sätt pekar Suslov på den begränsade betydelsen av ortodoxi i praktiken. Irina Kotkina också närmar sig konkreta kulturella produkter - i detta fall Wagners opera Tannhäuser som sattes upp på Novosibirsks teater - och visar att den 
nya kulturpolitiken i Ryssland använder ortodoxa värderingar i striden mot de kulturella produkter som anses kränka "statens säkerhet». Kotkina visar att kyrkan ibland kan använda censur i situationer när staten inte får göra det eftersom den sekulära lagstiftningen inte tillåter det.

Susan Ikonen analyserar Andrej Zvjagintsevs film Leviatan (2014) och drar paralleller mellan diskussioner om filmen i Ryssland och litteraturskandalen på 1950-talet som handlade om Vladimir Dudintsevs roman Icke av bröd allenast (1956) och Boris Pasternaks nobelpris i litteratur (1958). Ikonen visar att mottagandet av Leviatan speglar komplexa relationer mellan staten och kyrkan i dagens Ryssland samt den växande ryska patriotismen. Hon påpekar också att det sovjetiska arvet fortfarande påverkar både retorik och praktik i den ryska kulturpolitiken där västvärlden betraktas som en huvudfiende.

Även Andrey Makarychev analyserar filmrepresentationer i dagens Ryssland men i sitt kapitel närmar han sig motsvarigheter till Tjetjenienkrigen. Han påpekar en intressant paradox, nämligen att även om filmer skapar en positiv bild av patriotism, vänskap och gemenskap betyder det inte att de skapar positiva bilder av själva staten. Då blir patriotism någonting skilt från staten och ibland även någonting som står i motsats till staten.

Tomi Huttunen och Jussi Lassila analyserar Nationalbolsjevikiska partiet (NBP) genom att läsa Zakhar Prilepins litterära verk och intervjuer. Författarna påstår att rörelsens retorik kan karakteriseras som catachrestic politics (»katakrespolitik») - en politik som bygger på ett missbruk av konventionella begrepp och en praktik där politiska identiteter suddas bort. Huttunen och Lassila menar att kulturella eliter som saknade symboliskt kapital blev medlemmar i NBP i början av 1990-talet, och genom deras radikala retorik lyckades de skapa både politiska och kulturella kapital efter Sovjetunionens sammanbrott.

Sista kapitlet i boken närmar sig diskussionen om moderna och chassidiska judars identiteter i St. Petersburg. Jelena Ostrovskaja analyserar biografier av både moderna ortodoxa judar och Lubavitch-chassider och kommer till slutsatsen att moderna ortodoxa judar i sina biografier betonar vikten av autonomi och individuell vilja medan chassidiska judar i sina biografier betonar vikten av tradition.

Boken visar värdet av att analysera kyrkans och religionens roll i dagens ryska samhälle eftersom kyrkan och religionen i hög grad påverkar politik, kultur och samhälle. Varje kapitel i boken visar hur religionen genomsyrar alla områden, från försvaret till kulturutbudet. 